\title{
The Associations Between Vitamin D Receptor Bsml and Apal Polymorphisms and Obesity in Korean Patients with Type 2 Diabetes Mellitus
}

This article was published in the following Dove Press journal: Diabetes, Metabolic Syndrome and Obesity: Targets and Therapy

\author{
Sang Won Nam' \\ Jinwoo Choi ${ }^{1}$ \\ Hyun Jeong Jeon ${ }^{2}$ \\ Tae Keun $\mathrm{Oh}^{2}$ \\ Dong-Hwa Lee (1D) \\ 'Department of Internal Medicine, \\ Chungbuk National University Hospital, \\ Cheongju, South Korea; ${ }^{2}$ Department of \\ Internal Medicine, Chungbuk National \\ University College of Medicine, \\ Cheongju, South Korea
}

Background: Vitamin D receptor $(V D R)$ polymorphisms are associated with osteoporosis, diabetes, immunological diseases, and cancers. However, the association of obesity with $V D R$ polymorphisms has shown inconsistent results, and perhaps it depends upon the characteristics of a population. Therefore, we evaluated the association between BsmI (rs1544410) and ApaI (rs7975232) polymorphisms of VDR and obesity in Korean patients with type 2 diabetes mellitus (T2DM).

Methods: A total of 506 patients with T2DM participated in the study. Polymerase chain reaction-restriction fragment length polymorphism was used to analyze BsmI and ApaI polymorphisms; the genotypes were presented as $\mathrm{BB}, \mathrm{Bb}$, or bb for $\mathrm{BsmI}$ and $\mathrm{AA}, \mathrm{Aa}$, or aa for ApaI. Obesity was defined using the body mass index (BMI) with a cutoff level of $25 \mathrm{~kg} / \mathrm{m}^{2}$.

Results: The prevalence of obesity was higher in patients with the bb genotype than in those with $\mathrm{BB}$ or $\mathrm{Bb}$ genotypes (48.4\% vs $33.9 \%, \mathrm{P}=0.031)$. The mean BMI was $25.2 \pm 3.5 \mathrm{~kg} / \mathrm{m}^{2}$ in patients with bb genotype and $24.1 \pm 3.1 \mathrm{~kg} / \mathrm{m}^{2}$ in patients with $\mathrm{BB}$ or $\mathrm{Bb}$ genotypes. Patients with Aa or aa genotypes showed a higher prevalence of obesity than patients with AA genotype $(47.6 \%$ vs $26.1 \%, \mathrm{P}=0.043)$. Glycemic control parameters and lipid profiles did not show significant differences with either polymorphism.

Conclusion: To our knowledge, this is the first study to assess the association between $V D R$ polymorphisms and obesity in Korean patients with T2DM. Further studies in larger populations and multiethnic cohorts are needed to validate our findings.

Keywords: type 2 diabetes mellitus, obesity, vitamin D, vitamin D receptor gene, polymorphism

\section{Introduction}

Obesity is a common metabolic disorder and its prevalence is increasing worldwide. ${ }^{1}$ In Korea, the prevalence of obesity is rapidly increasing because of westernized diet and sedentary lifestyle; consequently, it has become a serious socioeconomic problem. ${ }^{2}$ According to an obesity fact sheet of Korea, the occurrence of obesity in adults increased from $29.7 \%$ in 2009 to $35.7 \%$ in 2018 . $^{3}$ Further, obesity is closely associated with increased risks of various chronic metabolic disorders, including diabetes mellitus (DM), hypertension, dyslipidemia, and cardiovascular diseases. ${ }^{1}$ According to the diabetes fact sheet in Korea, half of the patients with DM suffer from obesity. ${ }^{4}$ Therefore, the assessment and management of obesity is important to reduce obesity-related complications in a population.
Correspondence: Dong-Hwa Lee

Department of Internal Medicine, Chungbuk National University Hospital, 776,

I sunhwan-Ro, Seowon-Gu, Cheongju-si,

Chungcheongbuk-do, 28644, South Korea

Tel +82-43-269-7504

Fax +82-43-273-3252

Email roroko@hanmail.net
Diabetes, Metabolic Syndrome and Obesity: Targets and Therapy 2021:14 557-564 
Obesity results from the interactions between environmental and genetic factors. A previous study reported that genetic factors are responsible for approximately $40-70 \%$ of the etiology of obesity. ${ }^{5}$ Moreover, advanced technologies such as genome-wide association studies have led to the identification of some candidate obesity-related genes. ${ }^{6}$

The vitamin D endocrine system plays a central role in bone and calcium homeostasis. Apart from its classical involvement, vitamin D also plays an important role in other metabolic pathways in immune system, cancers, and other endocrine systems. ${ }^{7}$ Although vitamin D deficiency has been associated with obesity, ${ }^{8,9}$ the exact underlying mechanisms leading to obesity have not been fully determined yet; regardless, some possible explanations, such as insulin resistance and lipolysis have been suggested. ${ }^{10}$

Vitamin D receptor (VDR; a member of the steroid/ thyroid hormone receptor superfamily ${ }^{11}$ in complex with vitamin D serves as a transcription activator and regulates gene transcription by binding to vitamin $\mathrm{D}$ responsive elements, which are located in the promoter region of the target genes. Therefore, genetic alterations of VDR gene can alter gene activation, and lead to various diseases. ${ }^{7}$ Furthermore, $V D R$ gene is also expressed in adipocytes and pancreatic beta cells linked to insulin resistance and therefore it might be associated with body composition as well. ${ }^{12,13}$ More than 470 VDR polymorphisms have been identified in the $V D R$ gene. ${ }^{14}$ Among them, the wellestablished $V D R$ polymorphisms are as follows: FokI (rs2228570 C > T), BsmI (rs1544410 A > G), ApaI $($ rs7975232 $\mathrm{C}>\mathrm{T})$, TaqI $($ rs731236 $\mathrm{T}>\mathrm{C}$ ), and Cdx2 (rs11568820 A > G). ${ }^{15}$ A previous study has demonstrated that TaqI and BsmI polymorphisms are associated with obesity in French patients with type 2 diabetes mellitus (T2DM). ${ }^{16}$ In another study performed in the Thai population, the $\mathrm{Cdx} 2$ polymorphism was associated with a higher waist circumference; however, the four common polymorphisms (FokI, BsmI, ApaI, and TaqI) of the VDR gene did not show any association with BMI. ${ }^{17}$ In contrast, the VDR BsmI polymorphism has shown a significant association with vitamin D deficiency but not with the obesity phenotype in adolescents residing in Malaysia. ${ }^{8}$

So far, the previous studies have shown inconsistent results pertaining to the associations between $V D R$ polymorphisms and obesity. Furthermore, there is a lack of data regarding the same in the Korean population, especially the data of patients with T2DM who have a higher risk of obesity. Therefore, in this study, we evaluated the association between BsmI and ApaI polymorphisms of the $V D R$ gene and obesity in Korean patients with T2DM.

\section{Patients and Methods \\ Study Design and Participants}

This was a single-center, case-control study. Patients who were diagnosed with T2DM and treated at the Chungbuk National University Hospital, Korea, were included in the study. The diagnosis of T2DM was performed by the World Health Organization criteria. Patients with type 1 DM and other types of DM were excluded from this study. The demographic data including age, sex, height, weight, BMI, duration of DM, and family history of DM were collected through reviewing of medical records. Further, the laboratory data, such as fasting plasma glucose (FPG), hemoglobin A1c (HbA1c), C-peptide, insulin, and liver function, kidney function, and lipid metabolism parameters, were also investigated for each patient.

\section{Definition of Obesity}

BMI was used to evaluate obesity. The BMI $\left(\mathrm{kg} / \mathrm{m}^{2}\right)$ was calculated as baseline body weight $(\mathrm{kg})$ divided by the square of the height $\left(\mathrm{m}^{2}\right)$. Obesity was defined as a cutoff value of $25 \mathrm{~kg} / \mathrm{m}^{2}$ BMI, according to AsianPacific guidelines. ${ }^{18}$

\section{Genotyping of VDR Gene Polymorphic Variants}

The two polymorphisms of $V D R$, BsmI and ApaI, were analyzed in this study. Peripheral leukocytes were isolated from ethylenediaminetetraacetic acid-treated whole blood obtained from each patient. Then, the genomic DNA was extracted for subsequent polymerase chain reactions (PCR). All the included T2DM patients were genotyped using PCR-restriction fragment length polymorphism method, for two restriction sites in the VDR gene, BsmI and ApaI using specific primer sequences. The following BsmI and ApaI primers were used for amplification: (BsmI) forward 5'-CAA CCA AGA CTA CAA GTA CCG CGT CAG TGA-3' and reverse 5'-AAC CAG CGG AAG AGG TCA AGG G-3'. (ApaI) forward 5'GGG ACG CTG AGG GAT GGC AGA GC-3' and reverse 5'-GGA AAGGGGTTAGGTTGGACAGGA-3'. The primers of the $V D R$ gene were designed based on previous literature. ${ }^{19}$ The PCR condition used for Bsm I as followed: an initial denaturation of $3 \mathrm{~min}$ at $94{ }^{\circ} \mathrm{C}$, followed by denaturation of $30 \mathrm{~s}$ at $94{ }^{\circ} \mathrm{C}$, annealing of 30 
s at $62{ }^{\circ} \mathrm{C}$, and extension of $1 \mathrm{~min}$ at $72{ }^{\circ} \mathrm{C}$ for 30 cycles, and a final extension of $5 \mathrm{~min}$ at $72^{\circ} \mathrm{C}$. The PCR condition used for amplification of Apa 1 as follows; $94{ }^{\circ} \mathrm{C}$ for 10 min, and 30 cycles using the following temperature profile: $94{ }^{\circ} \mathrm{C}$ for $1 \mathrm{~min}, 62{ }^{\circ} \mathrm{C}$ for $1 \mathrm{~min}, 72{ }^{\circ} \mathrm{C}$ for $1 \mathrm{~min}$, and final elongation for $5 \mathrm{~min}$. The PCR products were digested overnight at $37{ }^{\circ} \mathrm{C}$ by Fermentas restriction enzymes, and then resolved in $1.5 \%$ agarose gel electrophoresis for the genotype analysis. We analyzed three genotypes for each polymorphism: $\mathrm{BB}, \mathrm{Bb}$, and $\mathrm{bb}$ for BsmI and AA, Aa, and aa for ApaI.

\section{Statistical Analysis}

The probability of Hardy-Weinberg equilibrium was tested using the chi-squared test. The data were expressed as the mean \pm standard deviation or as percentages for the categorical variables. The baseline characteristics were compared using Student's $t$-test for the continuous variables and chisquared test for categorical parameters. Multiple logistic regression analyses were performed to evaluate the relationship between obesity and the following variables: genotype, sex, age, duration of DM, hypertension, dyslipidemia, and HbA1c. All statistical analyses were performed using SPSS for Windows software 22.0 (IBM Corp., Armonk, NY, USA). The significance was set at $\mathrm{P}<0.05$.

\section{Ethics Statement}

The study was approved by the International Review Board of Chungbuk National University Hospital (IRB No. 2018-03-034-001) and conducted in accordance with the Declaration of Helsinki. All procedures were carried out with adequate understanding, and all patients gave their informed consent prior to being included in the study.

\section{Results}

\section{Clinical Characteristics of the Study Subjects}

A total of 506 patients (266 males and 240 females) were included in this study. The demographic and biochemical characteristics of the patients are shown in Table 1. The mean age and BMI of the patients were $62.6 \pm 10.6$ years and $25.1 \pm 3.5 \mathrm{~kg} / \mathrm{m}^{2}$, respectively. The mean duration of DM was $14.7 \pm 7.5$ years and approximately $51 \%$ of the patients had a family history of DM. The mean $\mathrm{HbAlc}$ and FPG values were $7.6 \pm 1.4 \%$ and $145.1 \pm 55.4 \mathrm{mg} / \mathrm{dL}$, respectively. The patients were categorized into "obesity group" and "normal weight group" depending upon their BMI values. The mean BMI was $27.9 \pm 2.9 \mathrm{~kg} / \mathrm{m}^{2}$ in the obesity group and $22.7 \pm 1.7 \mathrm{~kg} / \mathrm{m}^{2}$ in the normal weight group (P $<0.001)$. The proportion of females and prevalence of hypertension and dyslipidemia were higher in the obesity group than in the normal weight group. The duration of DM was shorter in the obesity group than in the normal weight group; however, family history of DM and serum HbAlc levels did not show significant differences between the two groups. The serum triglyceride levels were $172.6 \pm 120.3 \mathrm{mg} / \mathrm{dL}$ in the obesity group and $146.0 \pm 78.0 \mathrm{mg} / \mathrm{dL}$ in the normal weight group ( $\mathrm{P}=0.004)$. Finally, the liver enzymes, including aspartate aminotransferase (AST) and aspartate aminotransferase (ALT), were significantly higher in the obesity group than in the normal weight group.

\section{Various Parameters According to Bsml Genotypes}

Table 2 presents various parameters according to BsmI genotypes. Patients with the bb genotype (bb group) showed significantly higher BMI $\left(25.2 \pm 3.5 \mathrm{~kg} / \mathrm{m}^{2}\right)$ than patients with $\mathrm{BB}$ or $\mathrm{Bb}$ genotypes (BB $+\mathrm{Bb}$ group; $24.1 \pm 3.1 \mathrm{~kg} / \mathrm{m}^{2}$; $\mathrm{P}=0.034)$. However, no significant differences were observed between the glucose metabolism, lipid metabolism, and liver enzyme parameters of the two groups.

\section{Various Parameters According to Apal Genotypes}

The clinical parameters according to ApaI genotypes are shown in Table 3. The mean BMI was $25.1 \pm 3.5 \mathrm{~kg} / \mathrm{m}^{2}$ in patients with the Aa or aa genotypes (Aa + aa group) and $24.1 \pm 2.4 \mathrm{~kg} / \mathrm{m}^{2}$ in patients with AA genotype (AA group); however, the difference was not significant ( $\mathrm{P}=$ $0.180)$. Other laboratory findings were not significantly different between these two groups.

\section{VDR Polymorphisms and Obesity}

The frequencies of BsmI genotypes in the patients were as follows: BB, 2.0\% ( $\mathrm{n}=10)$; Bb, 10.3\% $(\mathrm{n}=52)$; and $\mathrm{bb}$, $87.7 \%(n=444)$. The frequencies of the ApaI genotypes in the patients were as follows: AA, $4.5 \%(n=23)$; Aa, $46.8 \%$ $(\mathrm{n}=237)$; and aa, $48.6 \%(\mathrm{n}=246$; Supplementary Table 1$)$. The bb group was significantly associated with a higher prevalence of obesity compared with the $\mathrm{BB}+\mathrm{Bb}$ group (48.4\% vs $33.9 \%$; $\mathrm{P}=0.031$; Table 4 ). Moreover, the $\mathrm{Aa}+$ aa group showed a higher prevalence of obesity than the AA group ( $47.6 \%$ vs $26.1 \%$; $P=0.043$; Table 4 ). Furthermore, we performed a logistic regression analysis of the risk factors 
Table I Baseline Characteristics of the Patients

\begin{tabular}{|c|c|c|c|c|c|c|c|c|c|c|}
\hline \multirow[b]{2}{*}{ Age (years) } & \multicolumn{3}{|c|}{ Total $(n=506)$} & \multicolumn{3}{|c|}{ Obesity Group $(n=236)$} & \multicolumn{3}{|c|}{ Normal Weight Group $(n=270)$} & \multirow{2}{*}{$\frac{P \text { value }}{0.040}$} \\
\hline & 62.6 & \pm & 10.6 & 61.6 & \pm & 11.0 & 63.5 & \pm & 10.1 & \\
\hline Sex (male/female) & 266 & l & 240 & 105 & l & $|3|$ & 161 & l & 109 & 0.001 \\
\hline Height $(\mathrm{cm})$ & 162.2 & \pm & 9.1 & 160.8 & \pm & 9.8 & 163.4 & \pm & 8.3 & 0.002 \\
\hline Body weight $(\mathrm{kg})$ & 66.1 & \pm & 11.4 & 72.4 & \pm & 11.8 & 60.7 & \pm & 7.7 & $<0.001$ \\
\hline Maximum body weight $(\mathrm{kg})$ & 74.1 & \pm & 12.7 & 80.4 & \pm & 12.3 & 69.7 & \pm & 11.1 & $<0.001$ \\
\hline Body mass index $\left(\mathrm{kg} / \mathrm{m}^{2}\right)$ & 25.1 & \pm & 3.5 & 27.9 & \pm & 2.9 & 22.7 & \pm & 1.7 & $<0.001$ \\
\hline Duration of DM (years) & 14.7 & \pm & 7.5 & 13.7 & \pm & 7.0 & 15.5 & \pm & 7.9 & 0.008 \\
\hline Family history of DM (n, \%) & 258 & & $(51.0)$ & 114 & & $(48.3)$ & 144 & & $(53.3)$ & 0.209 \\
\hline Hypertension (n, \%) & 339 & & $(67.0)$ & 172 & & (72.9) & 167 & & $(61.9)$ & 0.008 \\
\hline Dyslipidemia (n, \%) & 291 & & (57.5) & 150 & & $(63.6)$ & $14 \mid$ & & $(52.2)$ & 0.010 \\
\hline FPG (mg/dL) & 145.1 & \pm & 55.4 & 138.5 & \pm & 43.9 & 150.9 & \pm & 63.2 & 0.010 \\
\hline PP2 (mg/dL) & 208.0 & \pm & 77.4 & 210.9 & \pm & 79.8 & 205.4 & \pm & 75.2 & 0.448 \\
\hline $\mathrm{HbAlc}(\%)$ & 7.6 & \pm & 1.4 & 7.6 & \pm & 1.5 & 7.5 & \pm & 1.3 & 0.739 \\
\hline C-peptide $(\mathrm{ng} / \mathrm{mL})$ & 2.6 & \pm & 2.0 & 2.8 & \pm & 1.9 & 2.4 & \pm & 2.1 & 0.034 \\
\hline Insulin $(\mu \mathrm{IU} / \mathrm{mL})$ & 13.1 & \pm & 20.2 & 14.9 & \pm & 27.3 & 11.6 & \pm & 11.0 & 0.086 \\
\hline HOMA-IR & 4.8 & \pm & 8.7 & 5.3 & \pm & 11.9 & 4.4 & \pm & 4.7 & 0.273 \\
\hline Total cholesterol (mg/dL) & 170.3 & \pm & 33.7 & 170.4 & \pm & 33.4 & 170.1 & \pm & 34.0 & 0.916 \\
\hline Triglycerides (mg/dL) & 158.4 & \pm & 100.8 & 172.6 & \pm & 120.3 & 146.0 & \pm & 78.0 & 0.004 \\
\hline HDL-cholesterol (mg/dL) & 45.5 & \pm & 11.9 & 44.2 & \pm & 11.2 & 46.6 & \pm & 12.3 & 0.023 \\
\hline LDL-cholesterol (mg/dL) & 96.5 & \pm & 28.3 & 97.4 & \pm & 28.0 & 95.8 & \pm & 28.6 & 0.526 \\
\hline AST (IU/L) & 27.7 & \pm & 14.3 & 29.4 & \pm & 15.8 & 26.2 & \pm & 12.7 & 0.014 \\
\hline ALT (IU/L) & 31.0 & \pm & 22.8 & 33.2 & \pm & 22.3 & 29.0 & \pm & 23.2 & 0.036 \\
\hline BUN (mg/dL) & 16.5 & \pm & 8.4 & 16.4 & \pm & 8.6 & 16.5 & \pm & 8.2 & 0.843 \\
\hline Creatinine $(\mathrm{mg} / \mathrm{dL})$ & I.I & \pm & 0.8 & $\mathrm{I} . \mathrm{I}$ & \pm & 0.7 & 1.2 & \pm & 0.9 & 0.343 \\
\hline Urine ACR (mg/g) & 122.5 & \pm & 330.9 & 147.8 & \pm & 361.0 & 98.9 & \pm & 300.0 & 0.146 \\
\hline
\end{tabular}

Notes: Data are expressed as mean \pm standard deviation (SD). The $P$ values were calculated using Student's t-test for continuous data and chi-square test for categorical data between the obesity and normal weight groups.

Abbreviations: DM, diabetes mellitus; FPG, fasting plasma glucose; PP2, post-prandial 2 h glucose; HbAlc, hemoglobin Alc; HOMA-IR, homeostatic model assessment for insulin resistance; HDL, high-density lipoprotein; LDL, low-density lipoprotein; AST, aspartate aminotransferase; ALT, alanine aminotransferase; BUN, blood urea nitrogen; $A C R$, albumin to creatinine ratio.

associated with obesity, and the related data are shown in Table 5. The non-B allele of BsmI was significantly associated with obesity, and the odds ratio (OR) was $2.132(\mathrm{P}=$ 0.014). The a-allele of ApaI also showed a significantly high risk of obesity (OR was $2.711, \mathrm{P}=0.048$ ). Among other parameters, female sex, hypertension, and dyslipidemia were identified as the risk factors for obesity.

\section{Discussion}

In this study, we investigated the association between BsmI and ApaI polymorphisms in $V D R$ gene and obesity in Korean patients with T2DM. We found that patients with T2DM carrying the bb genotype of $V D R$ BsmI polymorphism were associated with higher BMI and increased risk of obesity than the $\mathrm{BB}$ or $\mathrm{Bb}$ genotypes. Although patients with the Aa or aa genotypes did not show significant differences in BMI (compared with the patients with AA genotype), the a-allele showed a significant correlation with obesity in the study population.
Recently, non-classical roles of vitamin D such as regulation of hormone secretion, immune function, cellular proliferation, and differentiation have emerged. ${ }^{20}$ Interestingly, previous studies have associated the effects of vitamin D with obesity. For instance, in a study of mixed-ethnicity participants, the individuals with obesity and those who were overweight showed a significant inverse correlation of serum 25-hydroxyvitamin D (25(OH)D) level with body weight, BMI, and waist circumference. ${ }^{21}$ Another study demonstrated that vitamin D affects energy expenditure through the upregulation of leptin gene expression. ${ }^{22}$ Further, the previous metaanalysis has reported that vitamin D deficiency is associated with obesity. ${ }^{23}$ Moreover, vitamin D improves insulin sensitivity; therefore, vitamin D deficiency may lead to the development of T2DM. ${ }^{24,25}$ Thus, these studies imply that vitamin D may play a possible role in obesity and obesity-related metabolic disorders.

Vitamin D binds to VDR to induce transcription pathways and gene expression. Therefore, genetic alterations of the $V D R$ 
Table 2 Various Parameters According to Bsml Genotypes

\begin{tabular}{|c|c|c|c|c|c|c|c|}
\hline \multirow[b]{2}{*}{ Age (years) } & \multicolumn{3}{|c|}{$B B+B b(n=62)$} & \multicolumn{3}{|c|}{ bb $(n=444)$} & \multirow{2}{*}{$\frac{\text { P value }}{0.415}$} \\
\hline & 63.7 & \pm & 10.9 & 62.5 & \pm & 10.5 & \\
\hline Height (cm) & 161.7 & \pm & 9.4 & 162.2 & \pm & 9.1 & 0.652 \\
\hline Body weight (kg) & 63.0 & \pm & 10.1 & 66.6 & \pm & 11.5 & 0.023 \\
\hline Body mass index $\left(\mathrm{kg} / \mathrm{m}^{2}\right)$ & 24.1 & \pm & 3.1 & 25.2 & \pm & 3.5 & 0.013 \\
\hline FPG (mg/dL) & 147.6 & \pm & 75.0 & 144.8 & \pm & 52.2 & 0.713 \\
\hline PP2 (mg/dL) & 205.2 & \pm & 72.6 & 208.4 & \pm & 78.1 & 0.769 \\
\hline HbAlc (\%) & 7.8 & \pm & 1.6 & 7.5 & \pm & 1.4 & 0.172 \\
\hline C-peptide (ng/mL) & 2.5 & \pm & 1.8 & 2.6 & \pm & 2.1 & 0.743 \\
\hline Insulin $(\mu \mid \mathrm{I} / \mathrm{mL})$ & 11.9 & \pm & 8.8 & 13.3 & \pm & 21.4 & 0.645 \\
\hline HOMA-IR & 4.4 & \pm & 3.4 & 4.9 & \pm & 9.3 & 0.720 \\
\hline Total cholesterol (mg/dL) & 171.3 & \pm & 37.8 & 170.1 & \pm & 33.2 & 0.795 \\
\hline Triglycerides (mg/dL) & 140.5 & \pm & 76.1 & 160.9 & \pm & 103.6 & 0.142 \\
\hline HDL-cholesterol (mg/dL) & 47.9 & \pm & 12.4 & 45.2 & \pm & 11.8 & 0.101 \\
\hline LDL-cholesterol (mg/dL) & 96.7 & \pm & 31.4 & 96.5 & \pm & 27.9 & 0.948 \\
\hline AST (IU/L) & 26.4 & \pm & 12.7 & 27.9 & \pm & 14.5 & 0.450 \\
\hline ALT (IU/L) & 28.9 & \pm & 21.6 & 31.2 & \pm & 23.0 & 0.459 \\
\hline
\end{tabular}

Notes: Data are expressed as mean \pm standard deviation $(\mathrm{SD})$. The $\mathrm{P}$ values were calculated using Student's $t$-test.

Abbreviations: FPG, fasting plasma glucose; PP2, post-prandial 2 h glucose; HbAlc, hemoglobin Alc; HOMA-IR, homeostatic model assessment for insulin resistance; HDL, high-density lipoprotein; LDL, low-density lipoprotein; AST, aspartate aminotransferase; ALT, alanine aminotransferase.

Table 3 Various Parameters According to Apal Genotypes

\begin{tabular}{|c|c|c|c|c|c|c|c|}
\hline \multirow[b]{2}{*}{ Age (years) } & \multicolumn{3}{|c|}{ AA $(n=23)$} & \multicolumn{3}{|c|}{$A a+a a(n=483)$} & \multirow{2}{*}{$\begin{array}{c}\mathbf{P} \text { value } \\
0.244\end{array}$} \\
\hline & 65.1 & \pm & 10.3 & 62.5 & \pm & 10.6 & \\
\hline Height (cm) & 161.2 & \pm & 8.5 & 162.2 & \pm & 9.2 & 0.606 \\
\hline Body weight (kg) & 62.8 & \pm & 7.8 & 66.3 & \pm & 11.5 & 0.149 \\
\hline Body mass index $\left(\mathrm{kg} / \mathrm{m}^{2}\right)$ & 24.1 & \pm & 2.4 & 25.1 & \pm & 3.5 & 0.180 \\
\hline FPG $(\mathrm{mg} / \mathrm{dL})$ & 163.6 & \pm & 39.9 & 144.2 & \pm & 55.9 & 0.102 \\
\hline PP2 (mg/dL) & 214.8 & \pm & 43.2 & 207.7 & \pm & 78.5 & 0.505 \\
\hline $\mathrm{HbAlc}(\%)$ & 8.1 & \pm & 2.1 & 7.5 & \pm & 1.3 & 0.202 \\
\hline C-peptide (ng/mL) & 3.1 & \pm & 4.0 & 2.6 & \pm & 1.9 & 0.589 \\
\hline Insulin $(\mu \mathrm{IU} / \mathrm{mL})$ & 30.9 & \pm & 80.6 & 12.2 & \pm & 9.8 & 0.302 \\
\hline HOMA-IR & 12.5 & \pm & 34.7 & 4.4 & \pm & 4.3 & 0.301 \\
\hline Total cholesterol (mg/dL) & 170.0 & \pm & 32.0 & 170.3 & \pm & 33.8 & 0.965 \\
\hline Triglycerides (mg/dL) & I54.I & \pm & 61.6 & 158.7 & \pm & 102.4 & 0.832 \\
\hline HDL-cholesterol (mg/dL) & 43.1 & \pm & 11.2 & 45.6 & \pm & 11.9 & 0.322 \\
\hline LDL-cholesterol (mg/dL) & 100.3 & \pm & 22.3 & 96.3 & \pm & 28.6 & 0.511 \\
\hline AST (IU/L) & 24.7 & \pm & 7.4 & 27.9 & \pm & 14.5 & 0.309 \\
\hline ALT (IU/L) & 29.2 & \pm & 13.6 & 31.0 & \pm & 23.2 & 0.703 \\
\hline
\end{tabular}

Notes: Data are expressed as mean \pm standard deviation $(\mathrm{SD})$. $\mathrm{P}$ values were calculated using Student's $t$-test.

Abbreviations: FPG, fasting plasma glucose; PP2, post-prandial $2 \mathrm{~h}$ glucose; HbAlc, hemoglobin Alc; HOMA-IR, homeostatic model assessment for insulin resistance; HDL, high-density lipoprotein; LDL, low-density lipoprotein; AST, aspartate aminotransferase; ALT, alanine aminotransferase.

gene may hinder the gene activation and functions. ${ }^{7}$ As $V D R$ expression has been found in adipose tissues, the association between obesity and $V D R$ polymorphisms has also been investigated. $^{8,9,16}$ In a study performed in French subjects with T2DM, BsmI and TaqI polymorphisms were associated with obesity; whereas ApaI did not show any significant correlation. ${ }^{16}$ This is in accordance with the results of our study. Another study showed that BsmI polymorphism was significantly associated with a higher BMI. ${ }^{26}$ Interestingly, conflicting results have been observed with respect to the association of obesity and ApaI polymorphisms. In a Chinese population, positive associations were observed between ApaI polymorphism and obesity (assessed by body fat percentage and skinfold thickness). ${ }^{27}$ In contrast, these associations were not observed in another study, which involved a study group of young Chinese males. ${ }^{28}$ In adolescents and young adults from 
Table 4 Association Between Genotypes of VDR Polymorphisms and Obesity

\begin{tabular}{|c|c|c|c|}
\hline & Obesity (n, \%) & Normal (n, \%) & $P$ value \\
\hline \multicolumn{4}{|l|}{ Bsml } \\
\hline$B B+B b(n=62)$ & $21(33.9)$ & $4 \mid(66.1)$ & 0.031 \\
\hline $\mathrm{bb}(\mathrm{n}=444)$ & $215(48.4)$ & $229(51.6)$ & \\
\hline \multicolumn{4}{|l|}{ Apal } \\
\hline $\mathrm{AA}(\mathrm{n}=23)$ & $6(26.1)$ & 17 (73.9) & 0.043 \\
\hline $\mathrm{Aa}+\mathrm{aa}(\mathrm{n}=483)$ & $230(47.6)$ & $253(52.4)$ & \\
\hline
\end{tabular}

Note: $\mathrm{P}$ values were calculated by chi-square test.

Table 5 Logistic Analysis of Risk Factors to Determine Their Association with Obesity According to VDR Polymorphisms

\begin{tabular}{|l|l|c|}
\hline & OR (95\% CI) & P value \\
\hline Non-B allele of Bsml & $2.132(1.164-3.903)$ & 0.014 \\
a-allele of Apal & $2.7 I I(1.007-7.302)$ & 0.048 \\
Sex & $2.082(1.425-3.04 I)$ & $0.00 I$ \\
Age $^{\mathrm{a}}$ & $0.854(0.710-1.026)$ & 0.093 \\
Duration of DM $^{\mathrm{b}}$ & $0.655(0.509-0.844)$ & $0.00 \mathrm{I}$ \\
Hypertension & $2.168(1.425-3.299)$ & $0.00 \mathrm{I}$ \\
Dyslipidemia $^{\text {HbAIc }}$ & $1.540(1.053-2.253)$ & 0.026 \\
\hline
\end{tabular}

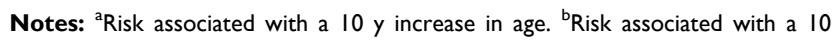
$y$ increase in duration of DM. ${ }^{c}$ Risk associated with a $1 \%$ increase in HbAlc.

Abbreviations: $\mathrm{OR}$, odds ratio; $\mathrm{Cl}$, confidence interval; $\mathrm{HbAlc}$, hemoglobin $\mathrm{Alc}$; DM, diabetes mellitus.

Spain and Malaysia, no significant associations were observed between the $V D R$ gene polymorphisms and obesity-related phenotypes. ${ }^{89}$ In recently published data, ApaI polymorphism appears to be correlated with overweightness and obesity in Chinese children. ${ }^{29}$ There are many ongoing studies and new SNP in VDR gene (rs3847987) have been shown an association with obesity phenotypes. ${ }^{30}$ Thus, to date, inconsistent results have been observed with respect to $V D R$ polymorphisms and obesity. We believe that these differences may be attributed to different parameters such as sex, age, ethnicity, and behavioral characteristics. Further studies are needed and obesity is closely related to the development of T2DM and has been attributed to the progression of diabetic complications via various mechanisms. ${ }^{31,32}$ Therefore, it is possible that VDR polymorphisms, which are related to obesity, may be responsible for these complications in patients with T2DM. Previous studies have reported an association between VDR polymorphisms and diabetic complications. ${ }^{33,34}$ Results from the logistic regression analysis showed that BsmI and ApaI polymorphisms were strong risk factors for obesity. Thus, our data imply a possible effect of $V D R$ polymorphisms on obesity in patients with T2DM, which is in accordance with the results of previous studies. ${ }^{16,26}$

To our knowledge, this is the first study to assess the association between the $V D R$ polymorphisms and obesity in Korean patients with T2DM. The present study was performed in relatively homogenous subjects with similar ethnicities and disease statuses. However, there are several limitations of our study. First, we did not evaluate the serum 25(OH)D level, therefore, we could not determine whether the patients had vitamin D deficiency. Second, the clinical characteristics related to obesity such as physical activity and diet were not evaluated. Moreover, other parameters assessing obesity including waist circumference and body composition could not obtain due to the retrospective study design. Third, there was no control group of individuals without T2DM. Finally, not all $V D R$ polymorphisms were investigated. Thus, we cannot rule out that other $V D R$ polymorphisms may also be associated with obesity in the studied population.

In conclusion, the present study demonstrated that BsmI and ApaI polymorphisms of the $V D R$ gene were associated with obesity in Korean patients with T2DM. However, further studies with larger multiethnic cohorts and experimental models are required to validate our results.

\section{Presentation}

Parts of this study were presented at the International Congress on Obesity and Metabolic Syndrome, Seoul, Korea, 6-9 September 2018.

\section{Ethical Statement}

All retrospective data involving human participants were in accordance with the ethical standards and with the 1964 Helsinki Declaration and its later amendments or comparable ethical standards. Ethical approval was obtained by the Local Ethics Committee.

\section{Author Contributions}

All authors made substantial contributions to conception and design, acquisition of data, or analysis and interpretation of data; took part in drafting the article or revising it critically for important intellectual content; agreed to submit to the current journal; gave final approval of the version to be published; and agree to be accountable for all aspects of the work. Everyone participated in the final approval of the manuscript. 


\section{Funding}

This research did not receive any specific grant from funding agencies in the public, commercial, or not-forprofit sectors.

\section{Disclosure}

The authors received no funding and report no conflicts of interest for this work.

\section{References}

1. Bluher M. Obesity: global epidemiology and pathogenesis. Nat Rev Endocrinol. 2019;15(5):288-298. doi:10.1038/s41574-019-0176-8

2. Park HS, Park CY, Oh SW, Yoo HJ. Prevalence of obesity and metabolic syndrome in Korean adults. Obes Rev. 2008;9 (2):104-107. doi:10.1111/j.1467-789X.2007.00421.x

3. Nam GE, Kim YH, Han K, et al. Obesity fact sheet in Korea, 2019: prevalence of obesity and abdominal obesity from 2009 to 2018 and social factors. $J$ Obes Metab Syndr. 2020;29(2):124-132. doi:10.7570/jomes 20058

4. Won JC, Lee JH, Kim JH, et al. Diabetes fact sheet in Korea, 2016: an appraisal of current status. Diabetes Metab J. 2018;42 (5):415-424. doi:10.4093/dmj.2018.0017

5. Barsh GS, Farooqi IS, O'Rahilly S. Genetics of body-weight regulation. Nature. 2000;404(6778):644-651. doi:10.1038/35007519

6. Xia Q, Grant SF. The genetics of human obesity. Ann N Y Acad Sci. 2013;1281(1):178-190. doi:10.1111/nyas.12020

7. Valdivielso JM, Fernandez E. Vitamin D receptor polymorphisms and diseases. Clin Chim Acta. 2006;371(1-2):1-12. doi:10.1016/j. cca.2006.02.016

8. Rahmadhani R, Zaharan NL, Mohamed Z, Moy FM, Jalaludin MY. The associations between VDR BsmI polymorphisms and risk of vitamin D deficiency, obesity and insulin resistance in adolescents residing in a tropical country. PLoS One. 2017;12(6):e0178695. doi:10.1371/journal.pone. 0178695

9. Correa-Rodriguez M, Carrillo-Avila JA, Schmidt-RioValle J, et al. Genetic association analysis of vitamin D receptor gene polymorphisms and obesity-related phenotypes. Gene. 2018;640:51-56. doi:10.1016/j.gene.2017.10.029

10. Chiu KC, Chu A, Go VL, Saad MF. Hypovitaminosis D is associated with insulin resistance and beta cell dysfunction. Am J Clin Nutr. 2004;79(5):820-825. doi:10.1093/ajcn/79.5.820

11. Mangelsdorf DJ, Thummel C, Beato M, et al. The nuclear receptor superfamily: the second decade. Cell. 1995;83(6):835-839. doi:10.1016/0092-8674(95)90199-X

12. Lee S, Clark SA, Gill RK, Christakos S. 1,25-Dihydroxyvitamin D3 and pancreatic beta-cell function: vitamin D receptors, gene expression, and insulin secretion. Endocrinology. 1994;134(4):1602-1610. doi:10.1210/endo.134.4.8137721

13. Mutt SJ, Hypponen E, Saarnio J, Jarvelin MR, Herzig KH. Vitamin D and adipose tissue-more than storage. Front Physiol. 2014;5:228. doi:10.3389/fphys.2014.00228

14. Uitterlinden AG, Fang Y, Van Meurs JB, Pols HA, Van Leeuwen JP. Genetics and biology of vitamin D receptor polymorphisms. Gene. 2004;338(2):143-156. doi:10.1016/j.gene.2004.05.014

15. Zmuda JM, Cauley JA, Ferrell RE. Molecular epidemiology of vitamin D receptor gene variants. Epidemiol Rev. 2000;22(2):203-217. doi:10.1093/oxfordjournals.epirev.a018033

16. Ye WZ, Reis AF, Dubois-Laforgue D, Bellanne-Chantelot C, Timsit J, Velho G. Vitamin D receptor gene polymorphisms are associated with obesity in type 2 diabetic subjects with early age of onset. Eur J Endocrinol. 2001;145(2):181-186. doi:10.1530/ eje. 0.1450181
17. Sangkaew B, Nuinoon M, Jeenduang N. Association of vitamin D receptor gene polymorphisms with serum 25(OH)D levels and metabolic syndrome in Thai population. Gene. 2018;659:59-66. doi:10.1016/j.gene.2018.03.047

18. Pan WH, Yeh WT. How to define obesity? Evidence-based multiple action points for public awareness, screening, and treatment: an extension of Asian-Pacific recommendations. Asia Pac J Clin Nutr. 2008;17(3):370-374.

19. Eltahir Khalid K. Vitamin D receptor gene polymorphisms in Sudanese children with type 1 diabetes. AIMS Genetics. 2016;3 (3):167-176. doi:10.3934/genet.2016.3.167

20. Bikle D. Nonclassic actions of vitamin D. J Clin Endocrinol Metab. 2009;94(1):26-34. doi:10.1210/jc.2008-1454

21. McGill AT, Stewart JM, Lithander FE, Strik CM, Poppitt SD. Relationships of low serum vitamin D3 with anthropometry and markers of the metabolic syndrome and diabetes in overweight and obesity. Nutr J. 2008;7(1):4. doi:10.1186/1475-2891-7-4

22. Kong J, Chen Y, Zhu G, Zhao Q, Li YC. 1,25-Dihydroxyvitamin D3 upregulates leptin expression in mouse adipose tissue. $J$ Endocrinol. 2013;216(2):265-271. doi:10.1530/JOE-12-0344

23. Manousopoulou A, Al-Daghri NM, Garbis SD, Chrousos GP. Vitamin D and cardiovascular risk among adults with obesity: a systematic review and meta-analysis. Eur J Clin Invest. 2015;45 (10):1113-1126. doi:10.1111/eci.12510

24. Teegarden D, Donkin SS. Vitamin D: emerging new roles in insulin sensitivity. Nutr Res Rev. 2009;22(1):82-92. doi:10.1017/ S0954422409389301

25. Palomer X, Gonzalez-Clemente JM, Blanco-Vaca F, Mauricio D. Role of vitamin D in the pathogenesis of type 2 diabetes mellitus. Diabetes Obes Metab. 2008;10(3):185-197. doi:10.1111/j.14631326.2007.00710.x

26. Hasan HA, AbuOdeh RO, Muda W, Mohamed H, Samsudin AR. Association of vitamin D receptor gene polymorphisms with metabolic syndrome and its components among adult Arabs from the United Arab Emirates. Diabetes Metab Syndr. 2017;11(Suppl 2): S531-S537. doi:10.1016/j.dsx.2017.03.047

27. Shen F, Wang Y, Sun H, et al. Vitamin D receptor gene polymorphisms are associated with triceps skin fold thickness and body fat percentage but not with body mass index or waist circumference in Han Chinese. Lipids Health Dis. 2019;18(1):97. doi:10.1186/s12944019-1027-2

28. Gu JM, Xiao WJ, He JW, et al. Association between VDR and ESR1 gene polymorphisms with bone and obesity phenotypes in Chinese male nuclear families. Acta Pharmacol Sin. 2009;30(12):1634-1642. doi:10.1038/aps.2009.169

29. Wang D, Su K, Ding Z, Zhang Z, Wang C. Association of vitamin $D$ receptor gene polymorphisms with metabolic syndrome in Chinese children. Int J Gen Med. 2021;14:57-66. doi:10.2147/IJGM.S287205

30. Yu S, Li X, Yu F, et al. New evidence for associations between vitamin $\mathrm{D}$ receptor polymorphism and obesity: case-control and family-based studies. J Hum Genet. 2020;65(3):281-285. doi:10.1038/s10038-019-0702-5

31. King GL. The role of inflammatory cytokines in diabetes and its complications. $J$ Periodontol. $2008 ; 79(8 \quad$ Suppl):1527-1534. doi:10.1902/jop.2008.080246

32. Bhupathiraju SN, Hu FB. Epidemiology of obesity and diabetes and their cardiovascular complications. Circ Res. 2016;118 (11):1723-1735. doi:10.1161/CIRCRESAHA.115.306825

33. Zhang $\mathrm{H}$, Wang $\mathrm{J}$, Yi B, et al. BsmI polymorphisms in vitamin $\mathrm{D}$ receptor gene are associated with diabetic nephropathy in type 2 diabetes in the Han Chinese population. Gene. 2012;495(2):183-188. doi:10.1016/j.gene.2011.12.049

34. Hong YJ, Kang ES, Ji MJ, et al. Association between Bsm1 polymorphism in vitamin $\mathrm{D}$ receptor gene and diabetic retinopathy of type 2 diabetes in Korean population. Endocrinol Metab. 2015;30 (4):469-474. doi:10.3803/EnM.2015.30.4.469 


\section{Publish your work in this journal}

Diabetes, Metabolic Syndrome and Obesity: Targets and Therapy is an international, peer-reviewed open-access journal committed to the rapid publication of the latest laboratory and clinical findings in the fields of diabetes, metabolic syndrome and obesity research. Original research, review, case reports, hypothesis formation, expert opinion and commentaries are all considered for publication. The manuscript management system is completely online and includes a very quick and fair peer-review system, which is all easy to use. Visit http://www.dovepress.com/testimonials.php to read real quotes from published authors. 